\title{
The Development Strategy of Agro-Industrial Tourism on New Normal Life in Bondowoso Regency, East Java
}

\author{
Tanti Kustiari* \\ Agribusiness Departmen \\ Politeknik Negeri Jember \\ East Java, Indonesia \\ tanti_kustiari@polije.ac.id
}

\author{
Nantil Bambang Eko Sulistyono \\ Agriculture Production Departmen \\ Politeknik Negeri Jember \\ East Java, Indonesia \\ besjember@polije.ac.id
}

Muksin

Agribusiness Departmen

Politeknik Negeri Jember

East Java, Indonesia

muksin@polije.ac.id

\author{
Nila Afila \\ Agribusiness Departmen \\ Politeknik Negeri Jember \\ East Java, Indonesia \\ nila.nafila2412@gmail.com
}

\begin{abstract}
In 2019, a global phenomenon was disturbed the stability of world economic conditions, namely the spread of a virus called Corona Virus Disease 2019 (Covid-19). Indonesia is one of the countries that is affected by the spread of Covid-19. It causes several sectors in all parts of Indonesia to be threatened with failure and loss, one of them is the Agro-Industry and the Tourism Sector in Bondowoso Regency. This condition requires all parties, especially agro-industry and tourism actors to handle and adjust to the current conditions so that they are able to survive in the new normal era (new normal life). This study aims to design an agro-industrial tourism development strategy in facing the new normal life in Bondowoso Regency. The research used Interpretative Structural Modeling (ISM) with 3 elements: factor elements, actor elements, and objective elements. The analysis results show the first key of sub-elements in the factor elements are Central Government Policy, Local Government Policy, Institutional Support, and Communication Model. The second key of sub-element in the actor element is the Bondowoso Regency Government. The he third key of sub-elements was business integration between the agro-industrial sector and the tourism sector, increasing product competitiveness, increasing the quality of agro-industry and tourism products, increasing learning, and efficiency effort.
\end{abstract}

\section{Keywords-development, ISM, strategy, tourism}

\section{INTRODUCTION}

Bondowoso has 34 tourist destinations that are spread across 33 districts. GeoparkIjen is one of the famous tourism destinations. The tourism that was established involved UMKM (MSME). Tours are managed by one party, but some are managed collaboratively. There are 5 types of managements that manage it, such as local government, collaboration between local government and forestry Service, collaboration between local government, forestry Service and village communities. For collaboration between local government and village communities are managed by village communities independently. Different tourism management shows adaptive capacities in post-covid-19 tourism recovery. It is interesting to know how to recover, capacity and ability to face health problems and the continuity of post-Covid-19 agro-industrial business.

Apart from the tourism sector, there is Bondowoso agriculture which is also very prominent. For $90,08 \%$ of BWO's land area is used for agriculture with main commodities such as mango, durian, banana, rice, corn, tuber, coconut and coffee. (BPS Statistics of Bondowoso Regency, 2018)[1]. Agricultural Products are processed into various processed products. There are processed products that are sold around tourist centers or in tourist areas. In the tourist area, MSMEs set up booths and shops that offer various snacks, drinks and foods. This is what the authors call the Agroindustry sector is integrated with tourism. The existence of agro-industrial tourism is able to provide employment for $35.18 \%$ of the workforce with low to high education levels (BPS Statistics of Bondowoso Regency, 2020)[2].

TABEL 1. NUMBER OF SMALL INDUSTRIES BY SUB-SECTOR INDUSTRY IN BONDOWOSO REGENCY

\begin{tabular}{lrrrrr}
\hline \multirow{2}{*}{ Type of Industry } & \multicolumn{5}{c}{ Number of Companies } \\
\cline { 2 - 6 } & $\mathbf{2 0 1 5}$ & $\mathbf{2 0 1 6}$ & $\mathbf{2 0 1 7}$ & $\mathbf{2 0 1 8}$ & $\mathbf{2 0 1 9}$ \\
\hline Food and Beverage & 9.120 & 9.120 & 9.120 & 9.465 & 9.437 \\
Clothing and Leather & 2.537 & 2.541 & 2.541 & 2.448 & 2.480 \\
$\begin{array}{l}\text { Chemistry and } \\
\text { Building }\end{array}$ & 1.027 & 1.027 & 1.027 & 1.027 & 1.168 \\
$\begin{array}{l}\text { General Handicraft } \\
\text { Industry }\end{array}$ & 5.883 & 5.898 & 5.898 & 5.898 & 5.965 \\
$\begin{array}{l}\text { Metals and Services } \\
\text { N }\end{array}$ & 1.382 & 1.411 & 1.411 & 1.411 & 1.338
\end{tabular}

Source: (BPS Statistics of Bondowoso Regency, 2017, 2018, 2019, 2020)

In the context of preventing the spread of the corona-19 virus, Bondowoso regional government from March 172020 to July 2020 closed the tourism place / entertainment sector and other non-important sectors, such as offices and shopping center for 3 months. Since the closure, socio-economic conditions in Bodowoso faced a decline. The existence of the Covid-19 pandemic has shaken the socio-economic 
conditions of various cities, both small cities and capitals (Muhyiddin, 2020). Not only in Indonesia, but other countries around the world are affected by the Covid-19 pandemic. The decline in the Turkish tourism are caused by travel restrictions for domestic and foreign tourists (Tanrıvermiş, 2020)[3]. Pakistan's economy faces decline. Declining and disrupting both financial and supply chain also decreasing demand and sales (Shafi, Liu, \& Ren, 2020)[4]. Chinese tourism destinations significantly faced socio-economic impacts due to the pandemic (Qiu, Park, Li, \& Song, 2020)[5]. In the UK about $7 \%$ per cent of SMEs have closed permanently due to the COVID-19 pandemic and many other are going to collapse (Amankwah-Amoah, Khan, \& Wood, 2020)[6]. The US economy has been drastically got the negative impact (Zeegen, Yates, \&Jevsevar, 2020)[7].

The closure policy of various sectors is studied nationally, the government predicts that the PSBB will lead to a prolonged crisis, so the government issues a New Normal policy and eases the PSBB (Muhyiddin, 2020)[8]. New normal life is a new way of life based on the new normal theory that humans adapt to the life condition during the Covid-19 pandemic. Covid-19 for over the months create new habit and behaviors in everyday life (Habibi, 2020)[9]. It is strengthened by the statement of the President of the Republic of Indonesia that people's lives must run but still have to keep safe from covid Covid-19. Therefore, the local government of Bondowoso No. 50/2020, starting July 11, 2020, reopened tourism by following the health protocol rules. However, only $40 \%$ of tourist destinations that meet the new normal requirements can be reopened. The total number of visitors decreased by only $23 \%$ in July 2020, from January 2020 , visitors were 72015 people. Many tourism places have not reopened due to lack of visitors, and $95 \%$ majority are local tourists. It is interesting to study the things that make tourism open again. Some of indicated factors of the readiness of health facilities, the actor of agro industrial tourism, the efficacy of the government, the number of visitors, the perception of the community and the government.

The main impact that has been faced by agro-industry and tourism actor is a decrease in income due to reduced customers even though tourist attractions have reopened. In certain zones, if there are high cases of Covid-19 infection, tourism in the village / city zone will be closed. Over the time, the existing agro-industrial tourism is going to collapse after pandemic. It is estimated that economic activities are not yet fully capable to transform into a new normal order, so it requires recommendations to revive people's economic activities yet still safe from the pandemic. Such as, Orientation to achieve economic and health saving factors.

Local economic rescue actions have been conducted. In any countries, giving tax deductions for certain commodities and giving compensation to anyone that is affected by the Covid 19 pandemic have been imposed (Djalante et al., 2020[10]). Turkish policies include prohibiting job dismissals, providing assistance or allowance, and encouraging the use of innovative technology (Tanrıvermiş, 2020)[3]. However, the policy steps are often not effective in saving people's lives from the threat of economic crisis and extinction. The job crisis will have an impact on the economic sustainability of the nation (Kumar, Luthra, Mangla, \&Kazançoğlu, 2020)[11].
The COVID-19 crisis spreads globally from 21st February to 24th March 2020 and still the case numbers of infection continue to grow rapidly every day. As a result, micro, small \& medium enterprises (MSME) become the main victim which is different with large companies, MSME usually do not have sufficient resources, especially financial and managerial (Shafi et al., 2020) [4]. Moreover, if the pandemic lasts longer, Donthu \& Gustafsson predict that it will likely lead to bankruptcy in many well-known industries, the travel industry and tourist destinations will not get any profit [12].

Now, the Covid 19 pandemic has been prolonged and the transmission rate is getting higher and wider. It is a dilemma, an effort to reduce the rate of spread by forcing people to stay at home and the economy to be closed, but on the other hand, it has given bad impact to MSMEs, the agro-industrial food will face difficulty to maintain its existence. The Covid 19 pandemic has not only caused national economy crisis but expanded globally. This creates a dilemma for policy makers. Even though the pandemic emergency situation has not ended, various economic activities, tourism, flights and so on are slowly being reopened. Therefore, this paper intends to evaluate and review the existence of small agroindustrial-food and tourism businesses in taking opportunities to recover from the prolonged COVID-19 pandemic situation. Sigala stated that the Covid pandemic is a transformational opportunity for tourism to become transformative e-tourism which has a value system, institutional logic, scientific paradigm, and technological ideas (Sigala, 2020) [13].

This study intends to limit the study of the impact of covid 19 on the agro-industrial tourism in Bondowoso regency that is far from the center of the metropolitan city, but what happens in the metropolitan area also gives impact to villages and surrounding districts. This requires a contribution of thought on how to maintain the agro-industrial tourism existence in the future. This paper aims to describe and evaluate systemically concerning key factors and objective elements that determine the operation of agro-industrial tourism system. This includes to evaluate institutional stakeholders in their contributive roles of agro-industrial tourism system during prolonged COVID-19 pandemic situation. The purpose of further writing is to design an agroindustrial tourism development strategy that is able to recover, survive, adapt and pass the non-natural disaster phase of Covid-19. The study implication reveals an effort to build a structural model of an adaptive transformational agroindustrial tourism, namely as how to take advantage of various opportunities that are in line with the demands of the COVID19 pandemic environmental situation.

\section{RESEARCH METHODS}

This study uses primary data and secondary data. Primary data was obtained from interviews with experts from June to July and followed by indept interviews in September 2020. Secondary data was data obtained from related agencies to complete primary data. Secondary data was used as supporting data in planning and formulating agro-industrial development strategies. Respondents in this study were Secretary of the Bondowoso Regency Agriculture Office, Head and staff of the Bondowoso Regency Tourism Office, and Agricultural Extension in Bondowoso Regency. 
Processing and data analysis in the study was conducted using the Interpretive Structural Modeling (ISM) method. ISM is a tool that can analyze decision making on understanding or ideas in complex situations by grouping and making connections that is available in a map (Indrawati, 2013) [14]. ISM was a tested and proven methodology for understanding and designing complex problem structures (Singhal, Tripathy, Jena, Nayak, \& Dash, 2018) [15].

The ISM technique can be used to conduct program analysis in accordance with the vision and mission (Rimantho \& Rosdiana, 2018) [16]. Structural models are produced to capture the complex problems of a system, through exact designed patterns using graphics and sentences (Sianipar, 2012) [17].

The formulation of a tourism-based agro-industrial sector development strategy using ISM is conducted in the following stages:

1) Identifying the variables or researched elements of several respondents. Through interviews in-depth discussions with experts resulted 3 important variables or elements.

a) The first elements of influence factors, namely the factors that is needed by the Bondowoso agroindustrial tourism sector towards an era of adaptation and returning to activities in the Covid-19 pandemic situation.

TABel 2. Determined Elements AND Sub Element FaCtors of AGRoINDUSTRIAL TOURISM

\begin{tabular}{cl}
\hline Code & Sub Element \\
\hline E1 & Human Resources (SDM) of agro-industry actors \\
E2 & Central Government Policy \\
E3 & Local Government Policy \\
E4 & Institutional Support \\
E5 & Sufficient Information and Communication Technology \\
E6 & Tourism facilities and infrastructure \\
E7 & Communication model \\
E8 & Marketing activities in the agro-industry and tourism sectors \\
E9 & Production processes and operational activities \\
\hline
\end{tabular}

b) The second element of actor who have a contributive role to prepare, implement and maintain and develop the agro industrial tourism sector, return to activities in the era of new normal life.

TABEL 3. ElEMENT AND Sub ElEMENT OF ACTORS

\begin{tabular}{cl}
\hline Code & Sub Element \\
\hline E1 & Bondowoso Regency Government \\
E2 & Agricultural Office of Bondowoso Regency \\
E3 & Tourism Office of Bondowoso Regency \\
E4 & State Owned Enterprises (BUMN) \\
E5 & Regional Owned Enterprises (BUMD) \\
E6 & Private Owned Enterprises (BUMS) \\
E7 & Financing institutions \\
E8 & Business Actor of Tourism based Agroindustry \\
E9 & Instructor \\
E10 & Business community \\
\hline
\end{tabular}

c) The third objective variable increase the capability of the agro-industrial tourism sector is able to return to the new normal life era. Its contains 9 sub elements (Table 4)
TABEL 4. OBJECTIVE ELEMENTS AND Sub-ELEMENTS

\begin{tabular}{cl}
\hline code & Sub Element \\
\hline E1 & Adapting to the conditions of the Covid-19 pandemic \\
E2 & $\begin{array}{l}\text { Business integration between the agro-industrial sector and the } \\
\text { tourism sector }\end{array}$ \\
E3 & Increase the added value and economy of local communities \\
E4 & Improve product competitiveness \\
E5 & Regional development \\
E6 & Expanding market reach \\
E7 & Improve the quality of agro-industrial and tourism products \\
E8 & Increase the learning of human resources (HR) of agro-industry \\
& and tourism actors in order to foster creativity \\
E9 & Business efficiency \\
\hline
\end{tabular}

2) Formulation of contextual relational link between the elements that were established using the Structural Self Interaction Matrix (SSIM). This formulation is conducted by assessing the contextual relational link in the pairwise comparison matrix, using the symbols $\mathrm{V}, \mathrm{A}, \mathrm{X}$ and $\mathrm{O}$ (Fadhil, Maarif, Bantacut, \&Hermawan, 2018) [18].

3) Change the SSIM matrix to Reachability Matrix (RM). The RM form is the binary matrix form. The next step is to classify the elements of the system into a map with 4 levels of autonomy, dependence, linkage and independence.

4) MICMAC analysis is an analysis in ISM which is used to analyze the driving force and dependability of a variable. This analysis is used to identify the key elements that drive the project by analyzing their driving force and dependability (Cai \& Xia, 2018) [19].

5) The model structure is an image that shows the position between the sub-elements in a hierarchy.

6) The final step in developing a policy strategy that is obtained from the analysis of the interpretive structural model.

\section{RESULTS AND DISCUSSION}

Based on the results of interviews with experts in the field of tourism, agriculture and community empowerment stakeholders in Bondowoso Regency, it produces 3 main elements, such as the determining factor element, the actor element, and the objective element from capable agro industrial tourism development model during a prolonged pandemic. Each element is described as follows:

\section{A. Elements of determining the capability of the agro industrial tourism to enter new normal life}

The results of the assessment from contextual relational link in the pairwise comparison matrix using the symbols $\mathrm{V}$, $\mathrm{A}, \mathrm{X}$ and $\mathrm{O}$ can be seen in the SSIM matrix., SSIM output is converted into determinant factor elements matrix RM of agro industrial tourism (Figure 1). Influencing factors, namely the factors needed by the agro industrial tourism sector in Bondowoso towards an era of adaptation and return to activities in the Covid-19 pandemic situation.

The MICMAC results and the model structure can be seen in figure 2 below, it shows that several sub-elements are classified into 3 levels, namely 4 key factor elements as driving factors (level 3). There is 1 relation of sub-element E1 which influences the dependent sub-element, namely E5, E6, $\mathrm{E} 8$, E9 (level 1), as long as E1 is driven by the strength of factors E2, E3, E4, E7. 


\begin{tabular}{|c|c|c|c|c|c|c|c|c|c|}
\hline & E1 & E2 & E3 & E4 & E5 & E6 & E7 & E8 & E9 \\
\hline E1 & & A & A & A & V & O & O & V & V \\
\hline E2 & & & V & V & V & V & X & V & O \\
\hline E3 & & & & V & V & V & X & V & O \\
\hline E4 & & & & & V & O & X & V & O \\
\hline E5 & & & & & X & A & X & O \\
\hline E6 & & & & & & A & X & X \\
\hline E7 & & & & & & & V & V \\
\hline E8 & & & & & & & & & O \\
\hline E9 & & & & & & & & & \\
\hline
\end{tabular}

Fig. 1. SSIM matrix on Determining Factor Element of Tourism Agroindustrial Capability of Bondowoso, East Java during The Covid-19 Pandemic

Based on these results can be seen that the Central Government Policy (E2), Local Government Policy (E3), Institutional Support (E4), and the communication model between the government, agro-industry actor and stakeholders (E7) are the key of sub elements that can influence the upper sub elements. So that, implementing policies that support agro-industrial tourism player from the central and regional governments, optimizing institutional roles and establishing communication between related parties need to be a priority in developing the agro-industrial tourism in Bondowoso Regency.

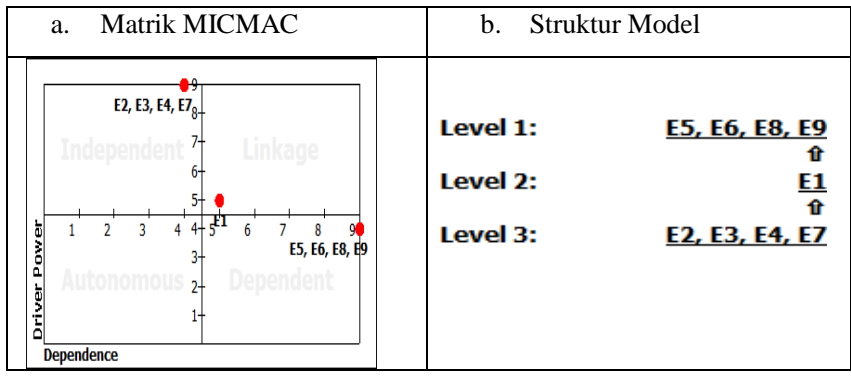

Fig. 2. a. MICMAC Analysis; b. Structure Model on Determinant Factor Elements of Agro-industrial Tourism of Bondowoso East Java during The Covid-19 Pandemic

The equations are the types of elements and sub-elements of the agro-industrial tourism that show able to survive in the covid-19 pandemic situation have been formulated into 9 subelement factors. These factors influence the the agro-industrial tourism sector in Bondowoso Regency, East Java, which is able return to the activities during the Covid-19 pandemic. Agro-industrial tourism does not only have economic motives but is also oriented towards upholding public health. The indications are agro-industrial tourism is in line with various demands for business sustainability, such as health protocol regulations compliance, availability of supporting infrastructure for the prevention of the corona-19 virus, and good business management. Tourism along with agroindustrial MSMEs is able to prepare offers of tourist attractions that are safe and comfortable for visitors,

Analysis of the development of the agro-industrial tourism in Bondowoso Regency shows the factors that are very influential and become a priority in the development of the agro-industrial tourism, such as 1) the existence of a Central Government Policy regarding the handling of agro-industry actors that affected by Covid-19. 2) the existence of a Regional Government Policy related to the acceleration of handling Covid-19 in Bondowoso Regency and refocusing the existing funds properly and fairly. 3) optimizing the role of institutions that support development such as pokdarwis, cooperatives and other institutions. 4) development of good and clear communication between the government, agroindustrial tourism actor and stakeholders that are involved in tourism-based agro-industry businesses.

\section{B. The Actor Element of the Bondowoso agro-industrial tourism}

The results of the identification of types of elements and several sub-elements of actors that have an influence in the agro-industrial tourism sector of Bondowoso Regency, East Java, showed that 9 sub-elements were successfully formulated (Figure 3).

The MICMAC results and structure model can be seen in Pigure 4 below, shows that several sub-elements are classified into 3 levels, such as the independent, linkage and dependent level actors. As many as 1 important element, namely the local government actor of Bondowoso Regency (E1) as the driving key actor for level 2 actor. Level 2 consist of 8 kinds of linkage level actors, that their existence is very much determined by actor E1. The actor of the linkage level is an actor who does not influence the important actor yet its role significantly affects the dependent sub-element, namely E8 (level 1 on Figure 4).

\begin{tabular}{|c|c|c|c|c|c|c|c|c|c|c|}
\hline & E1 & E2 & E3 & E4 & E5 & E6 & E7 & E8 & E9 & E10 \\
\hline E1 & & V & V & V & V & V & V & V & V & V \\
\hline E2 & & & X & X & X & X & X & V & V & X \\
\hline E3 & & & & X & X & X & X & V & O & X \\
\hline E4 & & & & & X & X & X & V & O & X \\
\hline E5 & & & & & X & X & V & O & X \\
\hline E6 & & & & & & X & V & O & X \\
\hline E7 & & & & & & & & V & O & X \\
\hline E8 & & & & & & & & & A & A \\
\hline E9 & & & & & & & & & X \\
\hline E10 & & & & & & & & & & \\
\hline
\end{tabular}

Fig. 3. SSIM Matrix on Actor Element Influence to Agro-industrial Tourism Sector of Bondowoso Regency, East Java

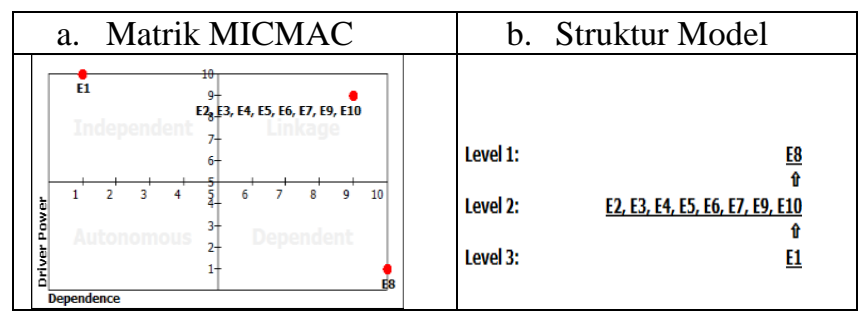

Fig. 4. a. MICMAC analysis; b. Element Model Structure of Actor That Affects to Agro-industrial Tourism Sector of Bondowoso Regency, East Java

Based on these results, it can be seen that the government of Bondowoso Regency (E1) is an actor who significantly influences the development of the agro-industrial tourism sector in this new normal life era. The Bondowoso Regency Government has the power to determine the direction of policy during the current crisis, so that the government is the only sub-element that can influence the other 9 elements.

The local government of Bondowoso Regency is believed to have an important role as a strong driving force in the growth of the capabilities of affected actors such as the agriculture agency, tourism service, BUMS, BUMD, extension agents, communities, and agroindustry business actors. The local government of Bondowoso district is believed to have the capability to restore economic and tourism conditions in its area and is believed to be able to use 
its power to establish an agro-industrial tourism recovery policy according to the requirements of new normal life after the Covid-19 pandemic

The government has a perception and believes that it will be able to restore the agro-industrial tourism (government efficacy) which is manifested in the making of regional regulations concerning the provisions of tourism health protocol requirements. Implementation assistance of reopening regulation for existed tourism place. But the fact is that not all tourism places can operate. Some of them that can open after Covid-19 such as the Ijen crater geopark, Kali Pahait, Almour, arak-arak, Tanjak Twin, Blawan Waterfall, and Megasari Peak. For $98 \%$ of the visitors come from within the country (July-September 2020). Most of the visitors are travelers who transit in Arak Arak area. Travelers that visit and stay less than 24 hours aim to use the tourism function as the most comfortable place to meet various needs, such as resting, worshiping, buying, parking, and using toilet (Kustiari $\&$ Taufik, 2017) [20]. The number of Bondowoso tourism visitors are around 17489 people per month. Since the tourism place was reopened from July to September 2020 (last article was written). Those data number of people are concentrated on reopened tourism places. In October 2020 there are 26 tourism places that have not reopened. Tourism place that is opened to the public due to the adequate number of visitors at each tourist destination. The total number of visitors to Bondowoso tourism place for 3 months after the Covid-19 pandemic (July - September) was only $23 \%$ of the total visitors before the Covid-19 pandemic. Many societies reduce and limit themselves to go out. This is related to people's perceptions. According to Fong et.al, the society has a positive view because it is based on their belief in the government's ability to work to properly control the Covid-19 pandemic (Fong, Law, \& Ye, 2020) [21]. The findings of Fong et al. Are correct with the conditions in Bondowoso, the spread of the covid-19 virus has increased, therefore the society will not be sure of the performance of the local government in preparing tourism according to the demands of new normal life. Therefore, the role of government actors is the key for tourism recovery. Tourism will recover and be ready to operate if it is supported by the role of the local government to increase capability and drive tourism actors to adapt the tourist attractions according to the needs of the new normal. Also, giving facility such as medical tool, adequate technology, travel instructions, Covid-19 handling management, and management of food serving that meets safety standards, comfort and cleanliness of tourism for every visitor.

\section{The Objective Element of Developing agro-industrial tourism when facing a Prolonged Covid Pandemic}

The identification result from type of development objective element and sub element of agro-industrial sector in Bondowoso Regency in the current prolonged COVID-19 pandemic situation there are 9 sub-elements of the objectives that were successfully formulated (Figure 5).

MICMAC and objective model structure of agro-industrial tourism development in facing covid 19 situation can be seen in figure 6 below. The results show there are 3 classifications, such as independent, linkage, and dependent. There are 7 objectives in the independent classification including the objectives of the code E1, E2, E3. E4, E7, E8, and E9. There are 7 types of objectives, which are the most important objective and most determine the other objectives at level 2 (linkage). Furthermore, the E6 code as the objective in the level 2 is a type of objective element that is determined by the main objective, when it will drive the achievement of the dependent classification objective (E5). The ultimate objective of the growing agro-industrial tourism in the Bondowoso area (E5) will be achieved, if it is supported by the ability to reach the agro-industrial tourism market (E6).

\begin{tabular}{|c|c|c|c|c|c|c|c|c|c|}
\hline & E1 & E2 & E3 & E4 & E5 & E6 & E7 & E8 & E9 \\
\hline E1 & & V & X & V & V & V & V & V & V \\
\hline E2 & & & V & V & V & V & V & V & V \\
\hline E3 & & & & X & V & V & X & A & V \\
\hline E4 & & & & & V & V & A & A & A \\
\hline E5 & & & & & A & A & A & A \\
\hline E6 & & & & & & A & A & O \\
\hline E7 & & & & & & & A & A \\
\hline E8 & & & & & & & & & V \\
\hline E9 & & & & & & & & & \\
\hline
\end{tabular}

Fig. 5. The SSIM Matrix on development Objective Element of Agroindustrial Tourism Sector of Bondowoso Regency, East Java in Prolonged Covid 19 Situation

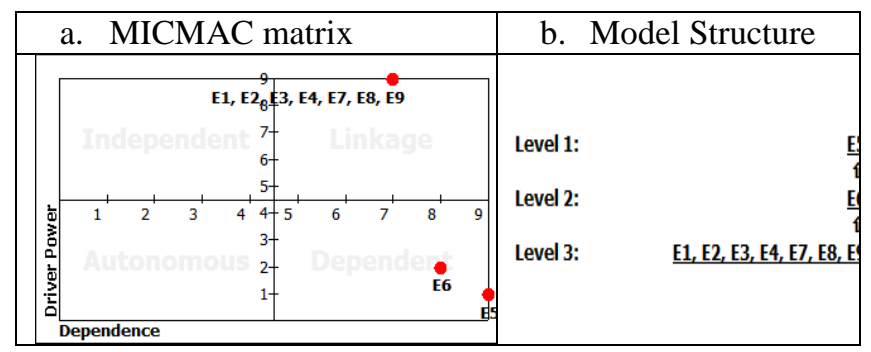

Fig. 6. a. MICMAC Analysis; b. Objective Element model structure of agro-industrial tourism development, Bondowoso East Java in Prolonged Covid 19 Situation

Based on these results it can be seen that adapting to New Normal Life (E1), integrating business between the agroindustry and tourism sectors (E2), increasing added value and the local economy (E3), increasing product competitiveness (E4), improving the quality of agro-industry and tourism products (E7), improving the learning of Human Resources (HR) of agro-industry and tourism actors (E8), and business efficiency (E9) are interrelated sub elements and the main objectives of the Bondowoso Regency government. If these objective are achieved, it will automatically affect to the development of market reach and regional development.

In the next discussion, the main objective factors in developing an agro-industrial tourism that can be used as a reference for all activities that are conducted by the government are 1) adapting to new conditions (New Normal Life), because the conditions before the pandemic and after the pandemic have quite large differences. 2) Business integration between the agro-industry and tourism sectors which can be independent without any diversion into other businesses. 3) Increasing the added value and economy of the local community through the development of other agrobusinesses that are possible in the new normal life era. 4) Increase the competitiveness of local agro-industrial products through the culture of "love Bondowoso products". 5) Improve the quality of agro-industry and tourism products and prepare themselves to face new normal life. 6) Increasing the learning of human resources (HR) of agro-industry and tourism actors. And 7) business efficiency needs to be 
conducted so that the agro-industry business actors do not lose profit which cause them to stop their business.

\section{The agro-industry tourism development model in the new normal life era}

At the beginning of the Covid-19 pandemic, all cultural tourism, natural tourism, artificial tourism, geoparks were closed by the government. During the tour closure for 3 months, namely April, May and June 2020, it will have an impact on the socio-economic tourism. Therefore, based on local government regulations in Bondowoso Regency, in July 2020 tourism will reopen with certain conditions.

Referring to the central policy that issued procedures for opening tourism after the Covid-19 pandemic, then gradually implementing the health protocol requirements. Some tours that do not yet have requirements are not granted an open permit. The government provides socialization that how to operate tours in the new normal era, educates tourism management. As long as it is in repairing supporting facilities for the prevention of Covid-19 as an adaptation effort for tourism in the new normal, the government will verify it first. If it is feasible, it will be given a sign label that is allowed to operate again.

The process of re-opening the tour is gradual. The tourism principles developed prioritize the achievement of adaptive capacity, integrity, value added, product quality, efficiency, competitiveness. If the tourist destination facilities do not meet the adaptive new normal requirements, the opening permit will be suspended until the tour is able to meet the requirements. How tourism can recover after the Covid-19 pandemic, can be seen in Figure 7 below about the agro-industry tourism development model that has the adaptation capacity according to the provisions of the era of new life habits.

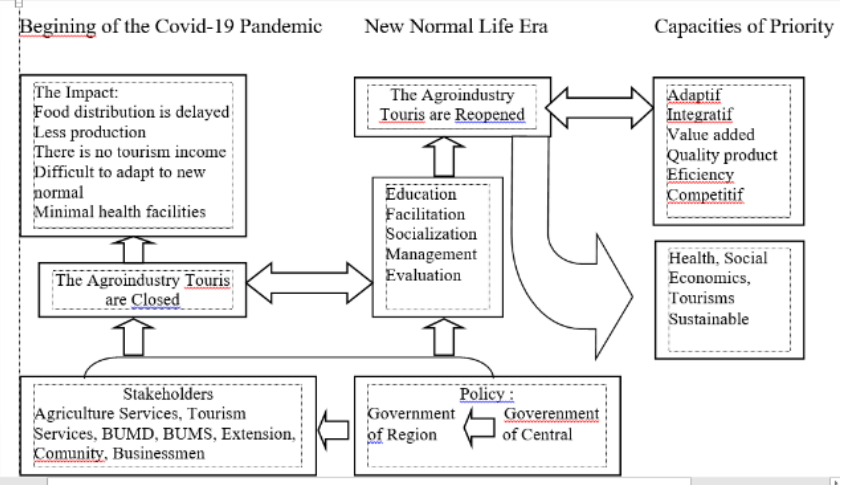

Fig. 7. Development Model of Agro-Industry Touris Capability in The New Normal Era.

\section{CONCLUSION}

Based on the analysis that has been conducted on the factors that influence the development of the agro-industrial tourism in Bondowoso Regency, it is capable of adapting to run the new normal agro-tourism, the key actors who influence the recovery of the agro-industrial tourism in Bondowoso Regency and the objective of developing the agro-industrial tourism in Bondowoso Regency, it can be seen that in facing new normal life, Bondowoso Regency government as the main actor needs to take tactical and strategic steps to develop the agro-industrial tourism sector in Bondowoso Regency.

The first strategic step that needs to be taken is to determine the objective of development the agro-industrial tourism in the current era of new normal life so that the government, related institutions, business actors and the community have clear references in the same view.

After knowing the objective achieved in this new normal life era, then what needs to be conducted is that the government establishes policies related to the development of the agro-industrial sector around tourism place which were closed due to the spread of Covid-19 so that business actors can continue to run their business and not facing big loss. This policy shall include refocusing the government budget so that it can be considered concerning distribution to agro-industrial tourism actor and not just the society.

\section{ACKNOWLEDGMENT}

Thanks to the student of post-graduate who have helped in data collection and input. The writers thank the Ministry of Research and Higher Education, Republic of Indonesia for the funding given to this research.

\section{REFERENCES}

[1] BPS Statistics of Bondowoso Regency, Bondowoso Regency in Figure 2018. 2018.

[2] BPS Statistics of Bondowoso Regency, Bondowoso Regency in Figure 2020, vol. VII. 2020.

[3] H. Tanrıvermiş, "Possible impacts of COVID-19 outbreak on real estate sector and possible changes to adopt: A situation analysis and general assessment on Turkish perspective," J. Urban Manag., no. August, pp. 1-7, 2020.

[4] M. Shafi, J. Liu, and W. Ren, "Impact of COVID-19 pandemic on micro, small, and medium-sized Enterprises operating in Pakistan," Res. Glob., vol. 2, p. 100018, 2020.

[5] R. T. R. Qiu, J. Park, S. N. Li, and H. Song, "Social costs of tourism during the COVID-19 pandemic," Ann. Tour. Res., vol. 84, no. April, p. 102994, 2020.

[6] J. Amankwah-Amoah, Z. Khan, and G. Wood, "COVID-19 and business failures: The paradoxes of experience, scale, and scope for theory and practice," Eur. Manag. J., no. xxxx, 2020.

[7] E. N. Zeegen, A. J. Yates, and D. S. Jevsevar, "After the COVID-19 Pandemic: Returning to Normalcy or Returning to a New Normal?," J. Arthroplasty, vol. 35, no. 7, pp. S37-S41, 2020.

[8] Muhyiddin, "Covid-19, New Normal, dan Perencanaan Pembangunan di Indonesia," J. Perenc. Pembang. Indones. J. Dev. Plan., vol. 4, no. 2, pp. 240-252, 2020.

[9] A. Habibi, Normal Baru Pasca Covid-19, vol. 4 No. 1. Adalah Buletin Hukum dan Keadilan, 2020.

[10] R. Djalante et al., "Review and analysis of current responses to COVID-19 in Indonesia: Period of January to March 2020," Prog. Disaster Sci., vol. 6, p. 100091, 2020.

[11] A. Kumar, S. Luthra, S. K. Mangla, and Y. Kazançoğlu, "COVID-19 impact on sustainable production and operations management," Sustain. Oper. Comput., vol. 1, no. July, pp. 1-7, 2020.

[12] N. Donthu and A. Gustafsson, "Effects of COVID-19 on business and research,” J. Bus. Res., vol. 117, no. June, pp. 284-289, 2020.

[13] M. Sigala, "Tourism and COVID-19: Impacts and implications for advancing and resetting industry and research," J. Bus. Res., vol. 117, no. June, pp. 312-321, 2020.

[14] C. D. Indrawati, "PASOK DENGAN PENDEKATAN INTERPRETIVE STRUCTURAL MODELING ( ISM )," no. 2004, pp. 1-12, 2013.

[15] D. Singhal, S. Tripathy, S. K. Jena, K. K. Nayak, and A. Dash, "Interpretive structural modelling (ISM) of obstacles hindering the remanufacturing practices in India," Procedia Manuf., vol. 20, pp. 452-457, 2018. 
[16] D. Rimantho and H. Rosdiana, "Penentuan Faktor Kunci Peningkatan Kualitas Air Limbah Industri Makanan Menggunakan Interpretative Structural Modeling (ISM)," J. Ilmu Lingkung., vol. 15, no. 2, p. 90, 2018.

[17] M. Sianipar, "Penerapan Interpretative Structural Modeling (ISM) dalam Penentuan Elemen Pelaku dalam Pengembangan Sistem Bagi Hasil Petani Kopi dan Agroindustri Kopi," Agrointek, vol. 6, no. 1, pp. 8-15, 2012.

[18] R. Fadhil, M. S. Maarif, T. Bantacut, and A. Hermawan, "Formulation for development strategy of gayo coffee agroindustry institution using Interpretive Structural Modeling (ISM)," Acta Univ. Agric. Silvic. Mendelianae Brun., vol. 66, no. 2, pp. 487-495, 2018.
[19] Y. Cai and C. Xia, "Interpretive Structural analysis of interrelationships among the elements of Characteristic Agriculture Development in Chinese rural poverty alleviation," Sustain., vol. 10, no. 3, 2018.

[20] T. Kustiari and M. T. Taufik H, "Destination Management of Religious Tourism in Cirebon Indonesia," vol. 128, no. Icet, pp. 2933, 2017.

[21] L. H. N. Fong, R. Law, and B. H. Ye, "Outlook of tourism recovery amid an epidemic: Importance of outbreak control by the government," Ann. Tour. Res., no. May, p. 102951, 2020. 